\title{
An Approach to the Identification and Characterisation of a Psychrotrophic Lipase Producing Pseudomonas sp ADT3 from Arctic Region
}

\author{
Arpita Dey ${ }^{1 *}$, Amarnath Chattopadhyay ${ }^{2}$, Pradipta Saha ${ }^{2}$, Subhrakanti Mukhopadhyay ${ }^{2}$, \\ Tushar Kanti Maiti ${ }^{3}$, Sabyasachi Chatterjee ${ }^{1}$, Pranab Roy ${ }^{1}$ \\ ${ }^{1}$ Department of Biotechnology, The University of Burdwan, Burdwan, India \\ ${ }^{2}$ Department of Microbiology, The University of Burdwan, Burdwan, India \\ ${ }^{3}$ Department of Botany, The University of Burdwan, Burdwan, India \\ Email: *arpitadey086@gmail.com
}

Received 4 January 2014; revised 12 February 2014; accepted 2 March 2014

Copyright (C) 2014 by authors and Scientific Research Publishing Inc.

This work is licensed under the Creative Commons Attribution International License (CC BY).

http://creativecommons.org/licenses/by/4.0/

c) (i) Open Access

\section{Abstract}

The aim of this research work was to explore psychrotrophic microbes from soil sample of NyAlesund, Svalbard, arctic region and to investigate their potential use as an effective tool for industrial application. A novel psychrotrophic bacterial strain showed good growth on minimal medium containing lipid as the only carbon source. Microbiological characterisation of the isolate showed that it was a gram negative rod. The strain was tested for the production of extracellular lipase enzyme. The enzymes were partially purified by $\mathbf{9 0 \%}$ saturated ammonium sulfate and dialysis for desalting. The bacterium was identified as Pseudomonas sp ADT3 by 16S rRNA amplification and sequencing which had been deposited in the NCBI GenBank with accession number JX914667. Phylogenetic tree was also constructed with MEGA5 software and showed the highest level of sequence similarity with Pseudomonas sp. HC3-13 strain. The microorganism had a growth optimum at $\mathrm{pH} 8.0$ and temperature $22^{\circ} \mathrm{C}$. Optimization of different parameters e.g. temperature, $\mathrm{pH}$, incubation time, cofactors etc. was performed for the extracellular lipase activity. The hydrolytic activity of the enzyme was enhanced 5 times by $\mathrm{Pb}^{2+}$ but strongly inhibited by heavy metals $\mathrm{Hg}^{2+}$ as well as EDTA and $\beta$-mercaptoethanol. For the molecular weight estimation of enzyme SDS-PAGE was done which showed an inducible band of approximately $13.9 \mathrm{KDa}$. Activity staining and mass spectrometry techniques were also performed.

\footnotetext{
${ }^{*}$ Corresponding author.
}

How to cite this paper: Dey, A., et al. (2014) An Approach to the Identification and Characterisation of a Psychrotrophic Lipase Producing Pseudomonas sp ADT3 from Arctic Region. Advances in Bioscience and Biotechnology, 5, 322-332. 


\section{Keywords}

\section{Psychrotrophic; Arctic; Extracellular Lipase; 16S rRNA; Mass Spectrometry}

\section{Introduction}

Microbial enzymes have a great number of usages in food, pharmaceutical, textile, paper, leather and other industries. Their applications have been increasing rapidly. Among industrially important enzymes, hydrolases come in the first place and include enzymes with wide substrate specificity. Carbohydrases, proteases, pectinases and lipases are classified into hydrolases. They catalyze the hydrolysis of natural organic compounds. We will focus on lipase from a cold-adapted bacterium in this particular study. Lipases belong to the class hydrolase (EC 3.1.1.1). It hydrolyzes acylglycerides into free fatty acids and glycerol [1] and also catalyzes a variety of organic transformations which are chemo-, regio-, enantio selective besides esterification under reduced non-aquous conditions [2] [3]. Due to such multifaceted properties, it is one of the important industrial enzymes that have found usage in a wide array of industrial applications, such as food, detergent, and chemical industry and also in biomedical sciences. Lipases are widely distributed in the earth's flora and fauna but are found more abundantly in microbial flora comprising bacteria, fungi and yeast [4]. For commercial bulk production, microbial sources are used, because of the great variety of catalytic activities available, the high yields possible, ease of genetic manipulation, regular supply due to absence of seasonal fluctuations and rapid growth of micro organisms or inexpensive media [5]-[10]. Microbial lipases are also more stable than their corresponding plant and animal enzymes and their production is more convenient, safer and can be obtained in bulk at low cost [11] [12]. There is growing interest in large scale purification of lipases. The chemo-, regio- and enantio-specific behaviour of these enzymes has caused tremendous interest among scientists and industrialists. Lipases from a large number of bacterial, fungal and a few plant and animal sources have been purified to homogeneity. Lipase producing bacterial sources is enormous but only few wild or recombinant strains have been used for commercial production of lipases.

Large area of the earth's surface is occupied by cold environments, such as the Arctic, Antarctic, alpine region, and abysses. Arctic soils can be considered an extreme environment colonized by special microorganisms, plants and animals which are adapted to these ecological niches. Many microorganisms are known as potential producers of extracellular lipases, including, yeast, and fungi [13] but there are few reports on extracellular lipase producing bacteria under cold condition [14]. The number of available lipases has increased since the 1980s. This is mainly a result of the achievements made in the cloning and expression of enzymes from microorganisms, as well as of an increasing demand for these biocatalysts with novel properties such as specificity, stability, $\mathrm{pH}$, and temperature [15] [16]. The present piece of work has been designed by taking the futuristic view and will provide a base for commercial exploitation of enzymes as an alternative to chemicals.

In the present communication isolation and identification of a psychrotrophic arctic Pseudomonas producing lipase, purification of the extracellular lipases and characterization were done to find out its usage in appropriate industry.

\section{Materials and Methods}

\subsection{Chemicals}

All chemicals used were of analytical grade, obtained from Himedia (India) and Sigma-Aldrich Company.

\subsection{Sample Collection}

The soil samples were collected from 6 different sites of Ny-Alesund ( $\left.78^{\circ} 56 " \mathrm{~N}, 11^{\circ} 54^{\prime \prime}\right)$ Svalbard, Arctic region during the Indian Arctic Expedition 2009, organized by National Centre for Antarctic and Ocean Research, Goa under the Ministry of Earth Science. During sampling and processing, careful attention was put to maintain sterile conditions. All soil samples were stored at $-20^{\circ} \mathrm{C}$.

\subsection{Isolation of Microorganisms}

$1 \mathrm{~g}$ of soil was used for enrichment in a medium that consisted of $0.5 \%(\mathrm{w} / \mathrm{v})$ glucose, $0.4 \%(\mathrm{w} / \mathrm{v}) \mathrm{NH}_{4} \mathrm{NO}_{3}, 0.1 \%$ 
(w/v) yeast extract, $0.025 \%(\mathrm{w} / \mathrm{v}) \mathrm{KH}_{2} \mathrm{PO}_{4}, 0.025 \%$ (w/v) $\mathrm{Na}_{2} \mathrm{HPO}_{4}, 0.1 \%(\mathrm{w} / \mathrm{v}) \mathrm{MgSO}_{4}$, and 0.5\% (v/v) Tween 20 [17] at $22^{\circ} \mathrm{C}$ for 10 - 15 days at uniform shaking. Enriched soil samples were then serially diluted and plated on minimal medium containing $0.3 \%(\mathrm{w} / \mathrm{v}) \mathrm{KH}_{2} \mathrm{PO}_{4}, 0.6 \%(\mathrm{w} / \mathrm{v}) \mathrm{Na}_{2} \mathrm{HPO}_{4}, 0.05 \%(\mathrm{w} / \mathrm{v}) \mathrm{NaCl}, 0.1 \%(\mathrm{w} / \mathrm{v})$ $\mathrm{NH}_{4} \mathrm{Cl}, 2 \mathrm{mM} \mathrm{MgSO}_{4}, 0.1 \mathrm{mM} \mathrm{CaCl}$ and $2 \%(\mathrm{w} / \mathrm{v})$ agar containing $1 \%(\mathrm{v} / \mathrm{v})$ olive oil at $\mathrm{pH} 8.0$ by spread plate method. Plates were incubated at $22^{\circ} \mathrm{C}$ for $48 \mathrm{hrs}$.

\subsection{Screening of the Isolates for Lipase Activity}

Lipolytic organisms were screened by qualitative plate assay. Isolates were grown on phenol red agar base plates and incubated at $22^{\circ} \mathrm{C}$ for 2 days. A change in colour was observed from red to yellow due to hydrolysis of olive oil to free fatty acid. Three isolates designated: ADT3, ADT4 and ADT5 showed positive result. The ADT3 isolate showing maximum zone of clearance was chosen for further investigation. The isolate was grown and subcultured in minimal medium slants with $1.0 \%$ olive oil.

\subsection{Morphological and Biochemical Characterisation}

The pure colony isolated was characterised by various biochemical tests using the Bergey’s manual of Determinative Bacteriology, as summarised in Table 1. The bacterial culture was streaked on respective plates containing tryptone agar, EMB (Eosin Methylene Blue) agar and blood agar. The plates were incubated at $22^{\circ} \mathrm{C}$ for 24 hrs. The different colony characters were recorded.

For antibiotic sensitivity test the bacterial culture was spreaded on Muller Hilton agar and the antibiotic octadisc combination (Himedia) placed on it. Plates were incubated at $22^{\circ} \mathrm{C}$ for $48 \mathrm{hrs}$.

\subsection{Scanning Electron Microscopy}

The morphology of the bacterium was studied using Hitachi, S530 SEM at University Science Instrumentation Centre; Burdwan University. The bacterium was fixed with glutaraldehyde ( $4 \% \mathrm{v} / \mathrm{v}$ stock) at $4^{\circ} \mathrm{C}$ for $4 \mathrm{hrs}$. After centrifugation, the cells were dehydrated by gradually lowering the concentration of alcohol: $95 \%$, 70\%, and $50 \%$. Cells were incubated 30 minutes in each of the alcohol concentrations followed by washing. Finally, the cells were diluted with $50 \%$ alcohol. One drop of this cell suspension was placed on a cover slip and studied with Hitachi, S530 SEM.

\begin{tabular}{cc} 
Table 1. Morphological and biochemical characterization. & \\
\hline Shape & Rods (Bacillus) \\
\hline Lactose Fermentation & Non-fermentative \\
Gram Character & Negative \\
Indole & Negative \\
Oxidase & Negative \\
$\mathrm{H}_{2} \mathrm{~S}$ & Positive \\
Catalase & Negative \\
Methyl red & Positive \\
Voges proskauer & Negative \\
Amylase & Negative \\
Gelatin & Positive \\
Endospore formation & Positive \\
Growth & Aerobic \\
pH range & $3-9$ \\
Optimum pH & 8.5 \\
Temperature range & $10^{\circ} \mathrm{C}-25^{\circ} \mathrm{C}$ \\
Optimum temperature & $22^{\circ} \mathrm{C}$ \\
NaCl range & $0.01 \mathrm{M}-2 \mathrm{M}$ \\
Optimum salt concentration & $0.8 \mathrm{M}$ \\
Growth in presence of oil & $0.5 \%-1.5 \%$ \\
Optimum olive oil concentration & $1 \%$ \\
\hline
\end{tabular}




\subsection{Physiological Characterisation}

\subsubsection{Temperature}

ADT3 cells were grown in minimal medium with $1.0 \%$ peptone and $1.0 \%$ olive oil and incubated at temperatures ranging from $10^{\circ} \mathrm{C}$ to $70^{\circ} \mathrm{C}$. Growth was determined by measuring O.D. at $620 \mathrm{~nm}$ after 48 hours.

\subsection{2. $\mathrm{pH}$}

ADT3 cells were grown in minimal medium with only olive oil as the carbon source $(1.0 \%)$ at $22^{\circ} \mathrm{C}$. $\mathrm{pH}$ was varied from 3 to 9. Optimum $\mathrm{pH}$ for growth was determined by measuring O.D. at $620 \mathrm{~nm}$ after $48 \mathrm{hours}$. $\mathrm{pH}$ was rechecked after the experiment.

\subsubsection{Carbon Source}

The ADT3 cells were grown in minimal medium with $0.2 \%, 0.4 \%, 0.6 \%, 0.8 \%$ and $1 \%$ of each of the carbon source respectively: fructose, glucose, sucrose, maltose and galactose. Growth in presence of different carbon source was determined by measuring O.D. at $620 \mathrm{~nm}$ at $24 \mathrm{hrs}, 48 \mathrm{hrs}$ and 72 hrs respectively.

\subsubsection{Substrate Concentration}

The cells were grown at $\mathrm{pH} 8$ in minimal medium with olive oil as the sole carbon source at $22^{\circ} \mathrm{C}$ for 48 hrs. The amount of olive oil added was varied from $0.1 \%$ to $1.5 \%$.

\subsubsection{NaCl Concentration}

Cells were grown in minimal medium with olive oil (1.0\%) as sole source of carbon at $22^{\circ} \mathrm{C}$ for 48 hrs, with salt concentration from $0.01 \mathrm{M}$ to $2 \mathrm{M}$. Optimum salt concentration for growth was determined.

\subsection{Identification of the ADT3 Isolate by $16 \mathrm{~S}$ rDNA Gene Amplification and Sequencing}

\subsubsection{DNA Extraction}

Cells obtained from $50 \mathrm{ml}$ culture were resuspended in lysis buffer [4.5 ml TE buffer, $100 \mu$ lysozyme (10 $\mathrm{mg} / \mathrm{ml}$ ), $450 \mu \mathrm{l}$ of $10 \% \mathrm{SDS}, 10 \mu \mathrm{l}$ of $20 \mathrm{mg} / \mathrm{ml}$ proteinase $\mathrm{K}$ ] and incubated for 1 hour at $37^{\circ} \mathrm{C}$. DNA was purified by phenol chloroform extraction and ethanol precipitation (Sambrook et al. 1989).

\subsubsection{S rRNA PCR Amplification}

The amplification was performed on $1.5 \mu \mathrm{l}$ DNA extract in $20 \mu \mathrm{l}$ using High Fidelity PCR System (GeneAmp PCR System 2400). PCR was carried out by using the universal primers: 27F: 5' AGA GTT TGA TCC TGG CTC AG 3' and 1492R: 5’ TAC GGY TAC CTT GTT ACG ACT T 3’ (Chromous Biotech Ltd., Bengaluru, India) [18]. Amplification reactions were performed in a $25 \mu \mathrm{L}$ volume, containing: $20 \mathrm{mmol} / \mathrm{L} \mathrm{Tris-HCl}(\mathrm{pH}=$ 8.4), $50 \mathrm{mmol} / \mathrm{L} \mathrm{KCl}, 2.0 \mathrm{mmol} / \mathrm{L} \mathrm{MgCl}_{2}, 200 \mathrm{umol} / \mathrm{L}$ of dNTPs, 1 umol/L of each primer, $30 \mathrm{ng}$ of genomic DNA and $1.5 \mathrm{U}$ of Taq DNA polymerase. The amplification conditions were: $94^{\circ}$ for 3 min for the first step, 30 cycles comprising of $94^{\circ}$ for $1 \mathrm{~min}, 52^{\circ}$ for $45 \mathrm{sec}, 72^{\circ}$ for $1 \mathrm{~min}$ and the final extension step of $72^{\circ}$ for $3 \mathrm{~min}$. The PCR product obtained was purified and sequenced by an automated DNA sequencer.

\subsubsection{Phylogenetic Analysis}

The forward and reverse sequences were assembled through DNABaser V35.0 software and submitted to GenBank through NCBI online sequence submission tool: Sequin V12.21. MEGA5 software was used to construct phylogenetic tree by aligning ADT3 sequence with reference sequences obtained from NCBI GenBank.

\subsection{Extraction of Crude Lipase}

On the day of maximum lipase activity in the lipase production medium, the culture was centrifuged at $10,000 \mathrm{~g}$ for $15 \mathrm{~min}$ at $4^{\circ} \mathrm{C}$ and the cell free supernatant was the source of crude extracellular lipase enzyme. The pellet so obtained was properly vortexed in Tris-HCl buffer, $\mathrm{pH} 8.0$ and used as intracellular lipase enzyme.

\section{Partial Purification of Enzyme}

The crude extracellular enzyme was subjected to different fractions of ammonium sulphate precipitation i.e. 0 - 
$10 \%, 10 \%-30 \%, 30 \%-50 \%, 50 \%-70 \%$ and $70 \%-90 \%$ with continuous stirring in magnetic stirrer overnight at $4^{\circ} \mathrm{C}$. The resulting precipitate was centrifuged $(15,000 \mathrm{xg})$ for $20 \mathrm{~min}$ at $4^{\circ} \mathrm{C}$, and the supernatants discarded. The crude precipitate was dissolved in minimal amount of $10 \mathrm{mM}$ Tris- $\mathrm{HCl}$ buffer of $\mathrm{pH} 8.0$, and then dialysed extensively against the same buffer overnight at $4^{\circ} \mathrm{C}$. The enzyme activities in the dialysate were again assayed.

\subsection{Determination of Lipid Hydrolysis by Titrimetric Assay}

Extracellular and intracellular lipase activity in bacterial culture supernatants after centrifugation $(12,000 \mathrm{~g}$ for $20 \mathrm{~min}$ ) was determined by titrimetric assay using olive oil as substrate. The reaction mixture contained $1 \mathrm{ml}$ of 0.1 M Tris-HCl buffer pH 8.0, $50 \mathrm{mM} \mathrm{KCL}, 200 \mu \mathrm{l}$ Tween 20, $1 \mathrm{ml}$ of olive oil as substrate, $1 \mathrm{ml}$ of culture supernatant at $22^{\circ} \mathrm{C}$ for $3 \mathrm{hrs}$. The reaction was stopped and fatty acids were extracted by addition of $3 \mathrm{ml}$ of ethanol. The amount of fatty acids liberated was estimated by titrating with $10 \mathrm{mM} \mathrm{NaOH}$ using phenophathalein indicator.

One unit of enzyme activity is defined as amount of alkali in $\mu \mathrm{Eq}(\mathrm{U})$ required neutralizing the fatty acids produced by hydrolysis of lipid (olive oil) per mg protein per hour.

\subsection{Extracellular Protein Profile of the Isolate}

\subsubsection{Extraction of Extracellular Proteins}

The cells were grown in two separate flasks. One in minimal M9 media containing $1 \%(\mathrm{v} / \mathrm{v})$ olive oil and in other set M9 with $1 \%(\mathrm{~W} / \mathrm{V})$ peptone for $48 \mathrm{hrs}$ at $22^{\circ} \mathrm{C}$. The cells were harvested by centrifugation at 12,000 rpm for 10 mins. The cell free supernatant was collected. The extracellular proteins were precipitated by $30 \%$ acetone overnight at $4^{\circ} \mathrm{C}$. Finally the proteins were dissolved in $0.1 \mathrm{M}$ Tris-HCl buffer $\mathrm{pH} 6.8$.

\subsubsection{Estimation of Protein}

Protein concentration was measured by the method of (Bradford, 1976) with bovine Serum albumin as a standard.

\subsubsection{SDS-PAGE of the Isolate}

Proteins were analyzed by sodium dodecyl sulfate polyacrylamide gel electrophoresis (SDS-PAGE) with a 12\% polyacrylamide resolving gel and a 5\% polyacrylamide Stacking gel [19].

\subsubsection{Gel Documentation System}

The protein gel was analysed in Gel documentation system (Vilbur Lourmat France) in Department of Biotechnology, Burdwan University.

\section{Results and Discussion}

10 colonies were isolated from the culture plate with lipid as sole carbon source. Most of the colonies were colourless with a few forming pigments. Among 10 isolates, one strain ADT3 showed maximal zone of clearance in phenol red plate assay which is further studied (Figure 1(a)).

\subsection{Morphological, Biochemical and Physiological Characterisation}

Colony formed on tryptone agar was smooth, glistening, and opaque with entire margins and deep cream in colour. Growth on eosin methylene blue (EMB) agar plate was of a pale tan colour indicating ADT3 to be a lactose non-fermenter.

ADT3 was gram negative in nature. Gram nature of the isolate was confirmed by treating a smear of the culture on a slide with $3 \% \mathrm{NaOH}$. Gram negative ADT3 instantly lysed and became viscous whereas a control gram positive bacillus was not affected by the alkali treatment [20]. SEM micrograph reveals that the cells are rod shaped of length $4.5 \mu \mathrm{m}$ and diameter $0.9 \mu \mathrm{m}$ (Figures 1 (b)). The results of experiments on Antibiotic sensitivity assay shows that ADT3 strain is resistant to Oxycillin and ampicillin (Figure 2).

\subsection{Analysis of $16 \mathrm{~S}$ rRNA PCR}

The PCR products were analyzed by electrophoresis on $1.5 \%$ agarose gels and stained with ethidium bromide. 100 bp ladder was used for evaluating the size of amplicons. Bands were obtained at $1.4 \mathrm{~kb}$ (Figure 3). 


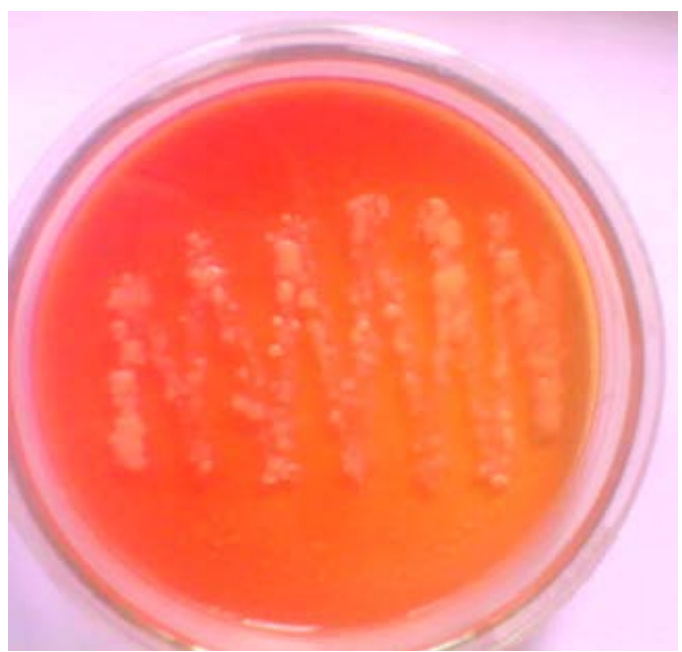

(a)

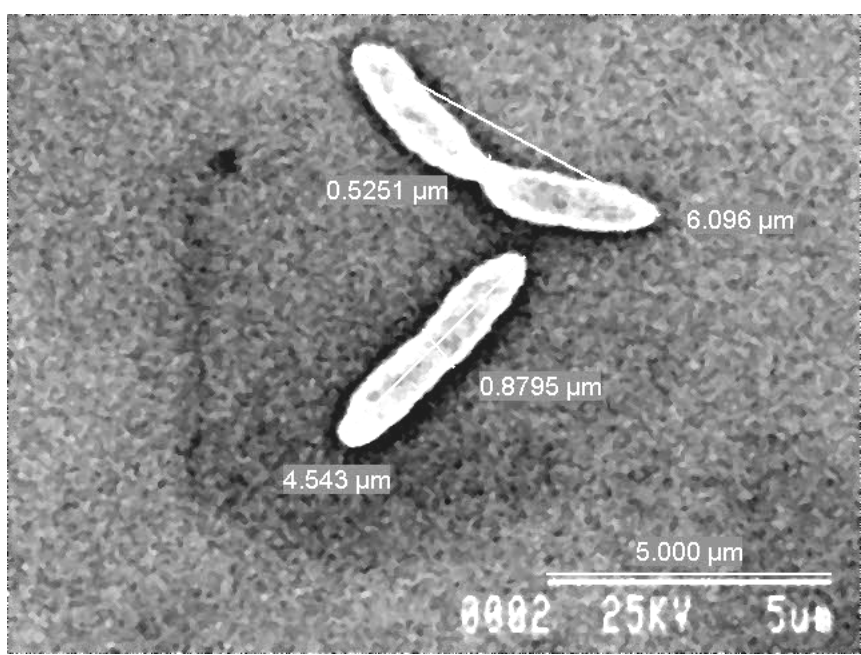

(b)

Figure 1. (a) Phenol red agar plate: ADT3 strain hydrolyzing the oil containing media with phenol red indicates the change in colour from red to yellow due to presence of lipolytic activity; (b) Scanning electron micrograph (Magnification $8000 \times$ ) Isolates were grown in rich medium at $22^{\circ} \mathrm{C}$ for $48 \mathrm{hrs}$ and fixed in $4 \%$ glutaraldehyde.

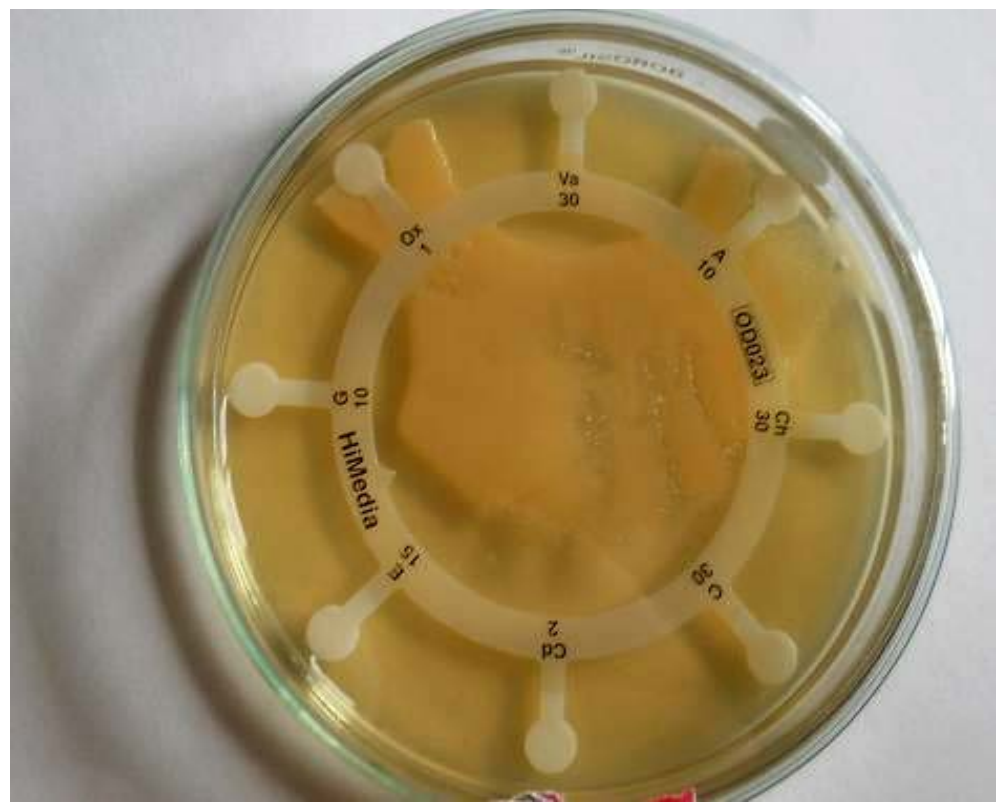

Figure 2. Antibiotic sensitivity assay: Antibiotic octadisc placed on ADT3 were incubated at $22^{\circ} \mathrm{C}$ for $48 \mathrm{hrs}$. Figure shows that ADT3 strain is resistant to Oxycillin and ampicillin.

\subsection{Sequencing and Computer Analysis 16S rRNA Genes}

For the validation of species identification, chosen strain was identified by 16S rRNA PCR pattern analysis on $1.5 \%$ agarose gel electrophoresis and those were selected for sequencing. The PCR amplified products were sequenced from Xcelris Labs, Ahmedabad, India. Species identification and similarity calculations were performed, comparing sequences of approximately 1500 bases of the 16S rRNA gene sequence of ADT3 with16S rRNA gene sequences retrieved from NCBI GenBank using nucleotide BLAST network services [21]. It showed 99\% similarity with Pseudomonas strain which belongs to the class Proteobacteriae and phylum Pseudomonadaceae. The 16S rRNA sequences in this study were submitted to the GenBank database by using Sequin software under nucleotide accession number of ADT3 as JX914667 (Table 2). 


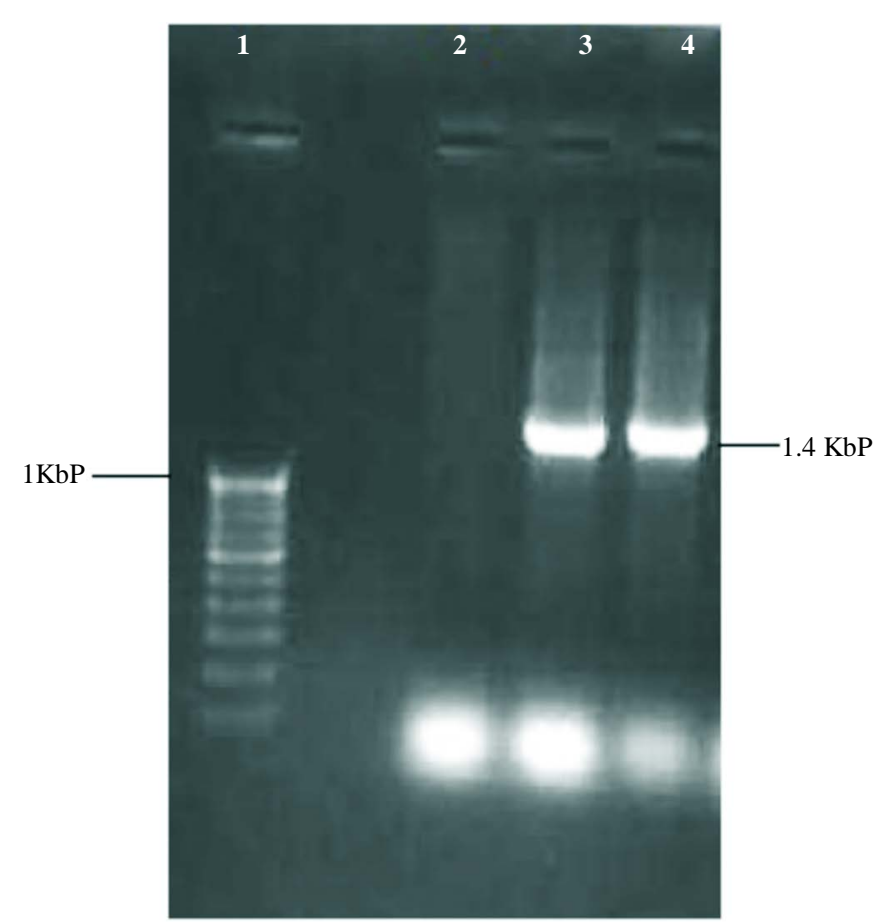

Figure 3. 1.2\% Agarose gel: The 16S rRNA PCR product of ADT3. Lanes 3 and 4 contain PCR product of $1.4 \mathrm{~Kb}$. Lane 2 had water as control. Lane 1 contains the 100 b.p. ladder.

Table 2. 16S rRNA gene sequence accession no. from NCBI GenBank.

\begin{tabular}{ccccccc}
\hline SI. No. & Sample ID & BLAST details & & \\
\hline & & Organism & $\begin{array}{c}\text { Gene Bank } \\
\text { accession no. }\end{array}$ & $\begin{array}{c}\text { Max } \\
\text { Score }\end{array}$ & $\begin{array}{c}\text { Query } \\
\text { coverage }\end{array}$ & $\begin{array}{c}\text { Max } \\
\text { Identity }\end{array}$ \\
01 & \multirow{2}{*}{ ADT3 } & $\begin{array}{c}\text { Pseudomonas sp. ADT3 } \\
\text { 16S ribosomal RNA gene }\end{array}$ & JX914667 & 2532 & $100 \%$ & $99 \%$ \\
\hline
\end{tabular}

\subsection{Phylogenetic Analysis of Pseudomonas spp. Based on 16S rRNA Sequence}

Multiple sequence alignment was done by CLUSTALW software (Figure 4). Phylogenetic relationship was outlined byMEGA5 software and found similarity index, distance using the neighbour joining method. ADT3 showed the highest level of sequence similarity with Pseudomonas sp. HC3-13 strain (Acc. No.JF312983.1) (Figure 5).

\subsection{Determination of Lipase Activity by Titrimetric Assay}

Specific activity of the lipase isolated from intracellular and extracellular fractions of ADT3 cells showed that $87 \%$ of the activity is extracellular and only $13 \%$ is intracellular. Hence, the cell supernatant was used as the source of enzyme in all studies. The lipase activity was measured titrimetrically and found $113.33 \mathrm{U} / \mathrm{mg}$ protein. Optimization of different parameters e.g. temperature, $\mathrm{pH}$, incubation time, cofactors etc. was performed for the extracellular lipase activity. The lipase activity was found to increase 5 times i.e. $527.77 \mathrm{U} / \mathrm{mg}$ protein in presence of $1.2 \mathrm{mM}$ lead when compared to control (result not shown).

\subsection{Extracellular Protein Profile of the Strain}

The extracellular protein profile of lipid grown cells shows one low molecular weight of $13.9 \mathrm{KDa}$ inducible band (Figure 6) which may be lipase which is faint in peptone grown cell. The band seems to be lipase which is confirmed by Mass-spectrometer and activity staining. 


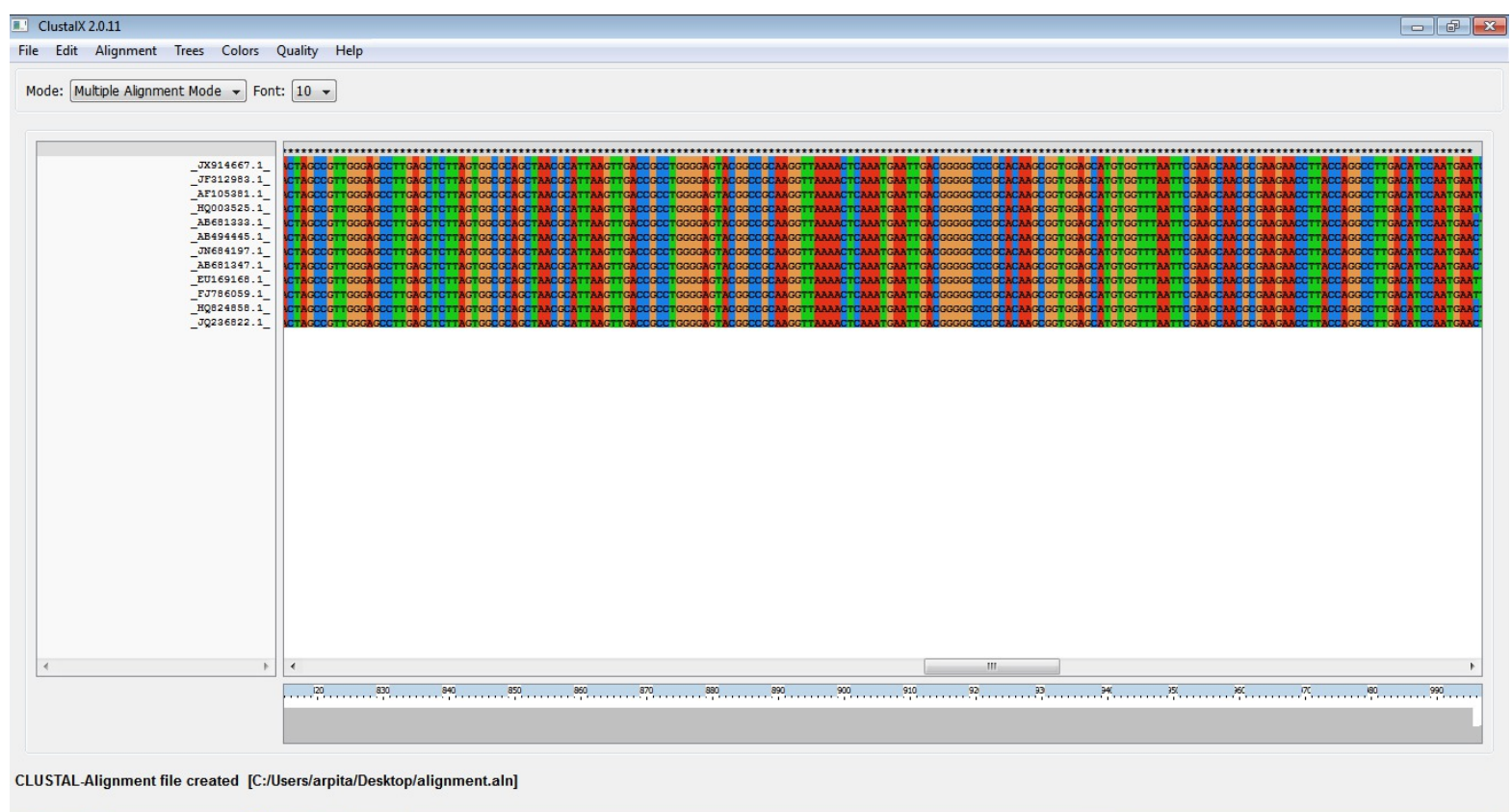

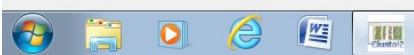

Figure 4. Multiple sequence alignment: Alignment of closely related 16S rRNA gene sequences of ADT3 (JX914667.1) retrieved from the NCBI GenBank with the software CLUSTAL W.

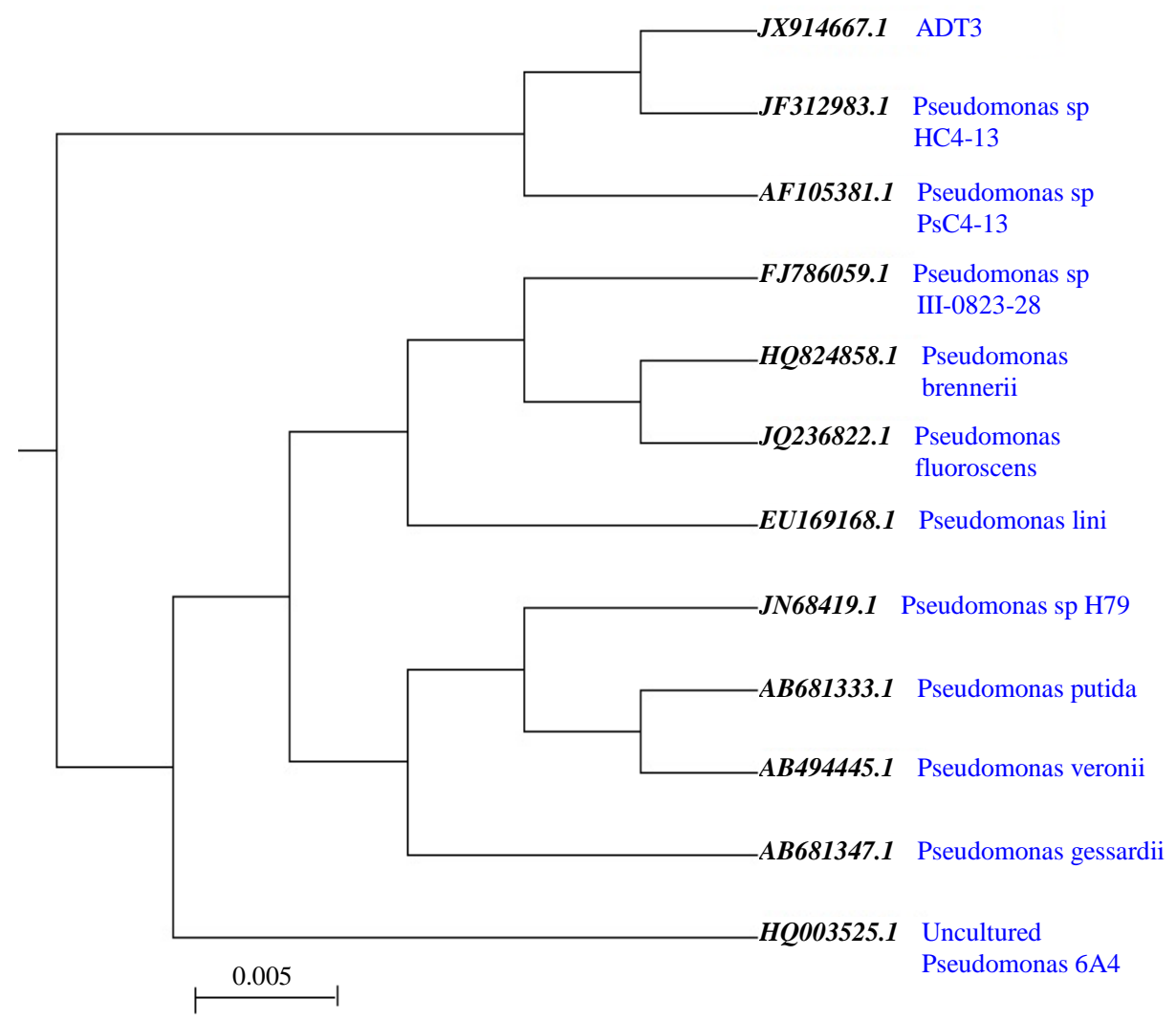

Figure 5. Neighbour joining tree based on ADT3 16S rRNA gene sequence comparison with $16 \mathrm{~S}$ rRNA gene sequences re-trieved from the NCBI GenBank, constructed using MEGA 5 software. The numbers in left are GenBank accession numbers. 


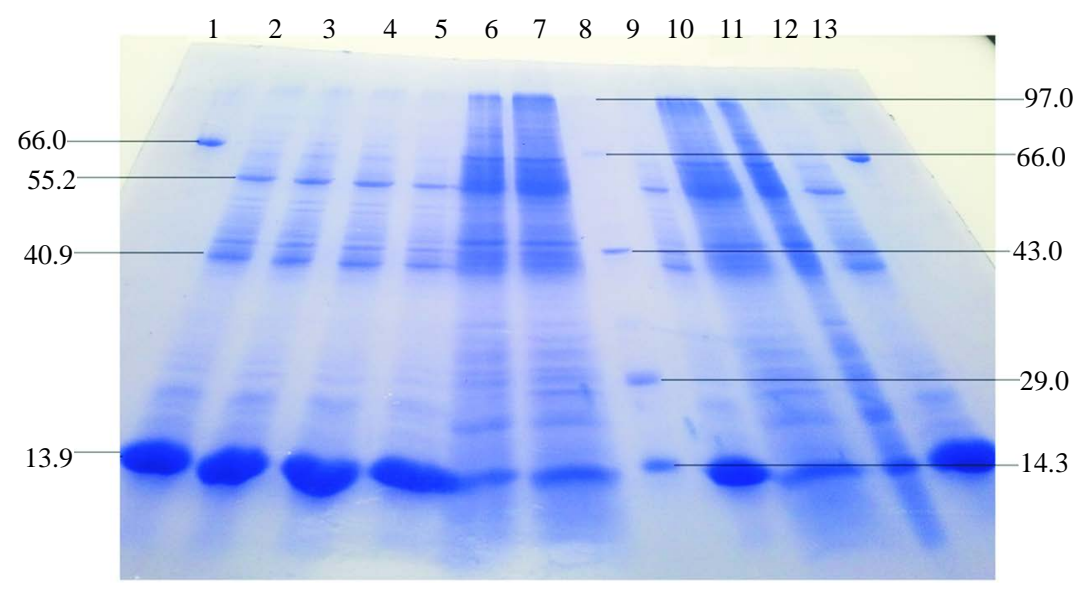

(a)

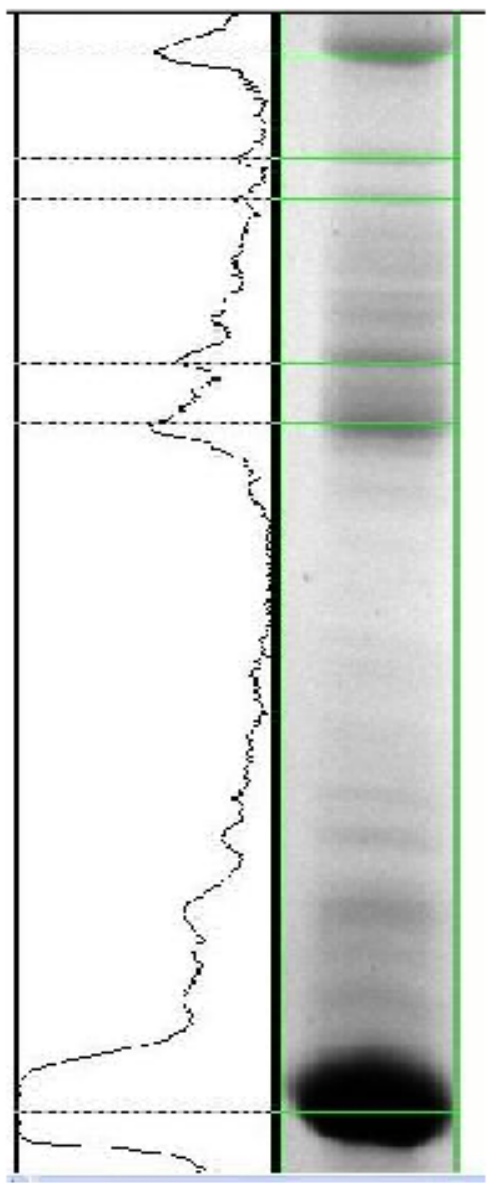

Lane 2 oil grown

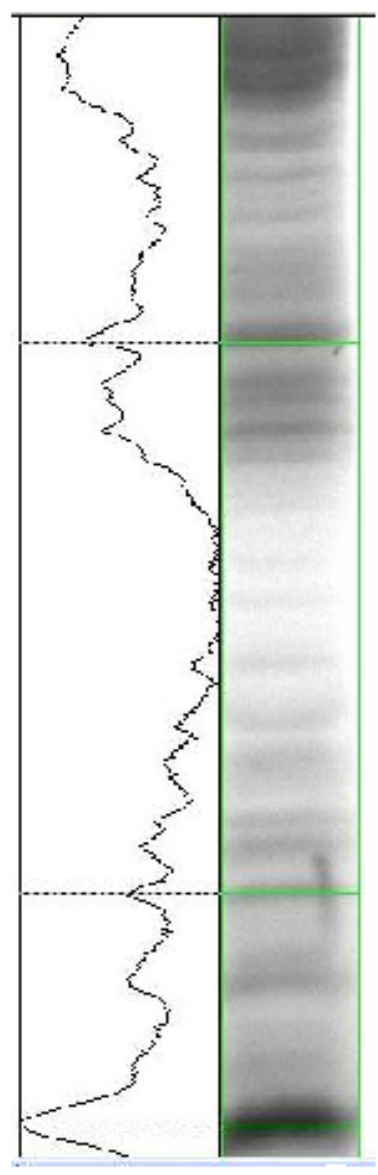

Lane 7 peptone grown

(b)

Figure 6. (a) 12\% SDS PAGE of ADT3 grown in peptone and only olive oil. Lanes 6 , 7, 10 and 11 show proteins extracted from ADT3 grown in 1.0\% peptone. Lanes 2, 3, 4, 5, 9 and 12 contains proteins obtained from ADT3 grown in 1.0\% olive oil. Lanes 1 and 13 contains BSA while lane 8 has molecular weight marker of medium and low range. All molecular weight markers are in kda; (b) Densitometric analysis of the $12 \%$ gel by Quantum Capt software showing the differential expression of proteins under varying culture conditions $1.0 \%$ olive oil and $1.0 \%$ peptone. 


\section{Conclusions}

The main purpose of this study was identification, characterization and partial purification of lipase enzymes isolated from arctic soil. Through polyphasic identification strategy this lipase producer was found to be a gram negative, non lactose fermenting Proteobacteria, highly similar (99\%) to Pseudomonas sp. The isolated bacterium was found to give its optimum temperature at $22^{\circ} \mathrm{C}$. The results obtained in this study show that olive oil is the most suitable substrate for maximum lipase production by Pseudomonas ADT3 strain. The enzyme exhibited maximum activity and stability at $\mathrm{pH} 3.5$ and $\mathrm{pH}$ 8.5. The enzyme has two isozymes which were hence confirmed by activity staining. The remarkable stability of Pseudomonas ADT3 lipase in this range has proved it to be a potential alkaline lipase similar to others, and a candidate for industrial applications such as detergent, leather and fine chemical industries. The lipase activity was found to increase 5 times i.e. $527.77 \mathrm{U} / \mathrm{mg}$ protein in presence of $1.2 \mathrm{mM}$ lead when compared to control i.e. $113.33 \mathrm{U} / \mathrm{mg}$ protein. The enzymatic activity of the isolated lipase producing strain Pseudomonas sp. is stimulated highly only by lead ions but not by other elements and inhibited by $\mathrm{Hg}^{2+}$ and EDTA. The mechanism of activation of this lipase by lead ions is not clear. But it is possible that lead ion binds to the core region of lipase in such a way that it leads to a change in conformation of active site. The lipase was relatively stable towards many metal ions and detergents tested. This characteristic made the enzyme suitable for lipase reactions under various conditions without special precautions.

For the protein determination of our enzyme, SDS-PAGE was done which showed approximately 13.9 KDa band. The induced band is confirmed to be lipase by activity staining and mass-spectrometry.

The characteristic of this presumably new enzyme of acting hydrolytically on fatty substrates without having to go through complicated, expensive and time consuming purification steps indicate that this enzyme would be suitable for low-scale production and utilization in industrial level. It would be recommended that the research involved in this enzyme's characterization should be continued in order to get a full image of its potential and its use in application. Further study must be performed in order to fully characterize the new lipase and design its production to serve environmental friendly purposes.

We are currently in the process of cloning this lipase gene and placing it under a strong promoter to be able to determine molecular properties of the lipase as well as increasing enzyme expression and yields for future industrial applications.

\section{Acknowledgements}

The authors thank National Centre for Antarctic and Ocean Research, Ministry of Earth Science, Goa, India for providing opportunity to be a part of Indian scientific expedition to Arctic in 2009 for sample collection. Financial support by Department of Science and Technology, New Delhi is also gratefully acknowledged. We thank Department of Biotechnology, Burdwan University for the facility to carry out the research work. Department of Microbiology, Burdwan University is also gtratefully acknowledged.

\section{Authors' Contribution}

The research work is really handled and designed by Arpita Dey. Pranab Roy contributes his intellectual input for the study.

\section{References}

[1] Jaeger, K.-E. and Eggert, T. (2002) Lipases for Biotechnology. Current Opinion in Biotechnology, 13, 390-397. http://dx.doi.org/10.1016/S0958-1669(02)00341-5

[2] Rubin, B. and Dennis, E.A. (1997) Lipases: Part A. Biotechnology Methods in Enzymology. Vol. 284, Academic Press, New York, 1-408.

[3] Kazlauskas, R.J. and Bornscheuer, U. (1998) Biotransformations with Lipases. In: Rehm, H.J. and Reeds, G., Eds., Biotechnology, Wiley-VCH, New York, 37-192. http://dx.doi.org/10.1002/9783527620906.ch3

[4] Pandey, A., Benjamin, S., Soccol, C.R., Nigam, P., Krieger, N. and Soccol, V.T. (1999) The Realm of Microbial Lipases in Biotechnology. Biotechnology and Applied Biochemistry, 29, 119-131.

[5] Saxena, R.K., Ghosh, P.K., Gupta, R., Davidson, W.S., Bradoo, S. and Gulati, R. (1999) Microbial Lipases: Potential Biocatalysts for the Future Industry. Current Science, 77, 101-115.

[6] Sharma, R., Chisti, Y. and Banerjee, U. (2001) Production, Purification, Characterization and Applications of Lipases. 
Biotechnology Advances, 19, 627-662. http://dx.doi.org/10.1016/S0734-9750(01)00086-6

[7] Iftikhar, T. and Hussain, A. (2002) Effect of Nutrients on the Extracellular Lipase Production by the Mutant Strain of $R$. oligosporous Tuv-31. Biotechnology, 1, 15-20. http://dx.doi.org/10.3923/biotech.2002.15.20

[8] Iftikhar, T., Haq, I.U. and Javed, M.M. (2003) Optimization of Cultural Conditions for the Production of Lipase by Submerged Fermentation of Rhizopus oligosporous Tuv 31. Pakistan Journal of Botany, 35, 519-525.

[9] Iftikhar, T., Niaz, M., Zia, M.A., Qadeer, M.A., Abbas, S.Q., Rajoka, M.I. and Haq, I.U. (2007) Screening of Media and Kinetic Studies for the Production of Lipase from a Mutant Strain of Rhizopus oligosporus. Biotechnologies International Symposium "Which Biotechnologies for South Countries”. Proceedings of Biotech World 2007, Oran Algerie, 24-25 November 2007.

[10] Ftikhar, T., Niaz, M., Hussain, Y., Abbas, S.Q., Ashraf, I. and Zia, M.A. (2010) Improvement of Selected Strains through Gamma Irradiation for Enhanced Lipolytic Potential. Pakistan Journal of Botany, 42, 2257-2267.

[11] Wiseman, A. (1995) Introduction to Principles. In: Wiseman, A., Ed., Hand Book of Enzyme Biotechnology, 3rd Edition, Ellis Horwood Ltd. T.J. Press Ltd. Padstow, 3-8.

[12] Vakhlu, J. and Kour, A. (2006) Yeast Lipases: Enzyme Purification, Biochemical Properties and Gene Cloning. Electronic Journal of Biotechnology, 9, 69-85. http://dx.doi.org/10.2225/vol9-issue1-fulltext-9

[13] Abada, E.A.E. (2008) Production and Characterization of a Mesophilic Lipase Isolated from Bacillus stearothermophilus AB-1. Pakistan Journal of Biological Sciences, 11, 1100-1106. http://dx.doi.org/10.3923/pjbs.2008.1100.1106

[14] Srinivas, T.N.R., Nageswara Rao, S.S.S., Vishnu Vardhan Reddy, P., et al. (2009) Bacterial Diversity and Bioprospecting for Cold-Active Lipases, Amylases and Proteases from Culturable Bacteria of Kongsfjorden and Ny-Ålesund, Svalbard, Arctic. Current Microbiology, 59, 537-547. http://dx.doi.org/10.1007/s00284-009-9473-0

[15] Bornscheuer, U.T., Bessler, C., Srinivas, R., et al. (2002) Optimizing Lipases and Related Enzymes for Efficient Application. Trends in Biotechnology, 20, 433-437. http://dx.doi.org/10.1016/S0167-7799(02)02046-2

[16] Menoncin, S., Domingues, N.M., Freire, D.M.G., et al. (2008) Study of the Extraction, Concentration, and Partial Characterization of Lipases Obtained from Penicillium verrucosum Using Solid-State Fermentation of Soybean Bran. Food and Bioprocess Technology, 3, 537-544. http://dx.doi.org/10.1007/s11947-008-0104-8.

[17] Choo, D.W., Kurihara, T., Suzuki T., et al. (1998) A Cold-Adapted Lipase of an Alaskan Psychrotroph. Pseudomonas sp. Strain B11-1: Gene Cloning and Enzyme Purification and Characterization. Applied and Environmental Microbiology, 64, 486-491. http://dx.doi.org/10.1007/s11947-008-0104-8

[18] Stackebrandt, E., Murray, R.G.E. and Truper, H.G. (1988) Proteobacteria Classis nov., a Name for the Phylogenetic Taxon Includes the "Purple Bacteria and Their Relatives". International Journal of Systematic and Evolutionary Microbiology, 38, 321-325. http://dx.doi.org/10.1099/00207713-38-3-321

[19] Laemmli, U.K. (1970) Cleavage of Structural Proteins during the Assembly of the Head of Bacteriophage T4. Nature, 277, 621-626.

[20] Gregersen, T. (1978) Rapid Method for Distinction of Gram Negative from Gram Positive Bacteria. Applied MicroBiology and Biotechnology, 5, 123-127. http://dx.doi.org/10.1007/BF00498806

[21] Altschul, S.F., Madden, T.L., Schäffer, A.A., Zhang, J., Zhang, Z., et al. (1997) Gapped BLAST and PSI-BLAST: A New Generation of Protein Database Search Programs. Nucleic Acids Research, 25, 3389-3402.

http://dx.doi.org/10.1093/nar/25.17.3389 